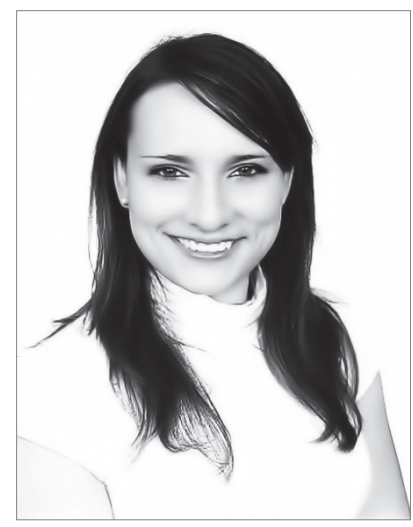

Ramutè Dabrytè - Klaipèdos universiteto magistrè. Moksliniai interesai: onomastika, motyvologija. El. paštas: rdabryte@yahoo.com.

Ramutè Dabrytè: MA student of Klaipeda University. Research interests: onomastics, motivology.

E-mail: rdabryte@yahoo.com.

\title{
Ramutè Dabrytè
}

Klaipédos universitetas

\section{KAIP PRASIVARDŽIUOJA ŠILALIŠKIAI?}

\begin{abstract}
Anotacija
Straipsnyje nagrinėjamos rytinèje Šilalès rajono dalyje, tiksliau - Kaltinėnų, Bijotų ir Upynos apylinkèse, užfiksuotos gyventoju pravardès. Asmenvardžiai klasifikuojami pagal motyvuojančius asmens bruožus. Detaliau apžvelgiamos ir aprašomos pravardžių motyvacinès grupès, nustatoma, kokie asmens bruožai labiausiai atkreipia šilališkių dėmesị. Pastebimi ir aptariami ypatingesni pravardžių formaliosios struktūros atvejai. Apžvelgus tiriamųjų apylinkių asmenvardžių motyvacijos statistiką, ji palyginima su visai Lietuvai ar atskiriems etnografiniams regionams būdinga pravardžių motyvacija.

PAGRINDINIAI ŽODŽIAI: pravardè, motyvacija, motyvacinė grupė.
\end{abstract}

\section{Abstract}

This article presents an analysis of the nicknames of the residents of the eastern part of Silale district, mainly Kaltinėnai, Bijotai and Upyna country-side districts. The nicknames are being classified according to some motivational personal features. The motivation groups of the nicknames are reviewed and described in details; moreover, it is established which personal features are mostly paid attention to by people from the Šilale district. Specific cases of the nicknames' formal structure are noticed and being discussed as well. After reviewing statistics of the examined districts nicknames motivation, it is compared to other nickname motivation of the whole Lithuania or separate ethnographic regions.

KEY WORDS: nickname, motivation, motivational group.

DOI: http://dx.doi.org/10.15181/rh.v17i1.1161

Lietuvių kalbotyroje daug dèmesio skiriama asmenvardžiams - jų kilmei, motyvacijai, formaliajai struktūrai, vartosenos ypatumams. Daugiausia tirti oficialieji asmenvardžiai, pravardžių tyrimai tebėra gana epizodiški, trūksta arealinès distri- 
bucijos ir chronologijos tyrinejimų. Išsamiau lietuviškos pravardès tirtos Alvydo Butkaus (1995) bei Žanetos Urbanavičiūtès ir V. Žičkutès (1974), regionines pravardes tyrinėjo Ona Aleknavičienė (2005, 2009), Marija Razmukaitė (1989).

Šio straipsnio tyrimo objektas - rytinès Šilalès rajono dalies (tiksliau - Kaltinėnų, Upynos ir Bijotu apylinkių) pravardès. Pravardès ekspedicijų metu iš gyvosios kalbos surinktos pačios autorès, medžiaga papildyta Klaipėdos universiteto Humanitarinių mokslų fakulteto Baltų kalbotyros ir etnologijos katedros Folkloro laboratorijos archyvo duomenimis. Beveik puse surinktų pravardžiu 90 iš 200 - lietuvių kalbotyroje nẻra užfiksuotos, būtent jos ir analizuojamos šiame straipsnyje.

Straipsnio tikslas - nustatyti rytinès Šilalès rajono dalies pravardžių motyvaciją. Darbe remtasi aprašomuoju, tiriamuoju-analitiniu ir lyginamuoju metodais.

Lietuvių kalbotyroje motyvacija paprastai apibrèžiama kaip žodžio ryšys su kitais žodžiais, morfemomis ar garsais, nusakančiais žodžio formaliosios sudèties parinkimą ir lemiančiais jo reikšmę (Jakaitienẻ 1980, 26; Gritėnienẻ 2006, 25). Kalboje visiškai nauju ir išgalvotų žodžių atsiranda labai mažai - jie kuriami pasitelkiant esamą kalbinę visumą, tad naujasis žodis kalboje turi pamatą ir yra motyvuotas (tai reiškia, jog pavadindami naują dalyką kartu nurodome, ir kodèl ji taip pavadiname, tai yra nurodome motyvaciją, pabréždami vienokią ar kitokią dalyko ypatybę) (Gudavičius 2000, 101). Tiriant ịvairias semantines grupes, ypač šnekamojoje kalboje vartojamus tam tikrų semantiniu grupių pavadinimus (pavyzdžiui, gyvūnijos, augalijos ar žmonių įvardijimo būdus), siekiama išsiaiškinti, kokie požymiai yra tipiškiausi, kokia motyvacija yra būdingiausia pavadinant konkrečią semantinę grupę sudarančią leksiką.

Suteikiant pravardes dominuoja subjektyvios - psichologinès priežastys: fiksuojamos išskirtinės, kolektyvo aplinkoje retai ar visai nepasitaikančios individo ypatybès. Dauguma pravardžių kuriamos dèl išvaizdos, veiklos, būdo, nes tai labiausiai krinta į akị. Galima sakyti, jog pravardès suteikimas atliepia tam tikrą bendruomenès tolerantiškumo lygị bei požiūrị i netipiškas ypatybes. Pravarde visuomenė subjektyviai išreiškia tam tikrą nukrypimą nuo bendruomenès normų ar net naudojasi kaip bendruomenès reguliavimo ar vertybių išraiškos forma (Wilson 1998, 283) ${ }^{1}$.

Pravardžių parinkimo priežastys, nulemiančios jų struktūrą ar apeliatyvinę reikšmę, gali būti ir onomastinès, kai gyvenamojoje aplinkoje (sėsliame, uždarame kolektyve, pavyzdžiui, kaime) nebepakanka standartinès dvinarès vardas + pavarde įvardijimo sistemos, atsiranda papildomo asmens įvardijimo, t. y. pravardès, poreikis. Tai vadinama onomastine motyvacija (LP 1995, 25). Tiriamosiose apylinkėse pastebėta nemažai bendravardžių bei bendrapavardžių. Nereta šeima turi tradiciją tèvų ar senelių vardą perduoti jaunesniajai kartai. Kartais pravardè, būdama taiklesnẻ bei parankesnè, šnekamojoje kalboje gali visai pakeisti ar net išstumti oficialiuosius vardus. 
Pagal motyvuojančius asmens bruožus tiriamąsias pravardes galima suklasifikuoti i tokias grupes: 1) pravardès dèl fizinių ypatybių; 2) pravardès dèl veiklos; 3) pravardès dèl būdo; 4) pravardès dèl kalbos turinio; 5) asociacinès pravardès; 6) gimininès pravardès; 7) pravardès dèl gyvenamosios vietos.

1. Pravardès dèl fizinių ypatybių. Daugiau nei trečdalis tiriamųjų pravardžių suteiktos dẻl išorinių žmogaus ypatybių - atspindima tai, kas ryškiausiai išsiskiria regèjimo, klausos, uoslès lauke. Pagal konkretesnes semantines ypatybes tiriamoji motyvacinè grupé suskyla į smulkesnius pogrupius:

a) išvaizda. Ji yra kiekvieno individuali, labiausiai reprezentuojanti ir leidžianti išskirti iš kitų. Išvaizda visada užkliūva pirmu žvilgsniu, tad šis pogrupis apima pravardes, nusakančias tik išorinius žmogaus kūno bruožus. Pagal ryškiausią motyvuojančio žodžio semantinị požymį tiriamosiose apylinkèse daugiausia pravardžiu radosi dèl žmogaus kompleksijos bei ūgio: Spyglỹs ,,aukšto ūgio ir plonas“, Rutulỹs f. „stora ir žema“, Smálbačke f. „stora“, Štrùlis „,storulis“2, Cỹrule f. „labai nedidelio ūgio“, Strùkjuzè f. „maža ir stora“, Smilgẽle f. „labai stora“, Žãgris „lieknas ir aukštas“. Perpus mažiau pavyzdžiu, nurodančiu plaukų ypatybes: Žalvarìnis „pagal plaukų spalvą“, Skiauterẽ f. „pagal šukuoseną“, Baltplaũkè f. „turi juodus kaip čigonès plaukus“, Sar̃čius ,pagal plaukų spalvą, panašią i a arklio, vardu Sartis““3. Po vieną kitą pavyzdi pasiskirsto nosies - Didnõsè f. „su didele nosimi“, Trumpnõsis „itin didelès nosies“; $\underline{\text { ùsu }}$ ar barzdos - Barzylà „turi didelę barzdą“, Ūsû̃rinis „turi ilgus ūsus“"; drabužiu - Surdùkas „,nešiojo karvès odos imitacijos pižamą“, Raibókas „dèvi raibus drabužius“; veido - Baltrìmkis „,balto veido“, Gražuoliùkas „,negražaus veido“; koju - Varmakõjis „plonų kojų“, Klumbakójis „klišų kojų“; panašumas i koki personažą - Mãšenka f. „panaši į animacinio filmuko veikejją Mašenką", Šopokliãka f. „eina pašokčiodama“; bei akiụ ypatybès - Sprogtãkis „didelių akių“;

b) motorika. Pogrupis apima pravardes, nusakančias dinaminę žmogaus išvaizdą, t. y. eiseną ir kitus kūno judesius: Trydẽnis „kalbẻdamas daug gestikuliuoja“, Klišóji f. „,raiša“, Plùpe f. „,eina dideliais žingsniais“;

c) kalba. Šiam klasifikaciniam pogrupiui priskirtinos pravardès, žyminčios žmogaus kalbos intensyvumą bei balso tembrą: Bùrba „greitai kalbẻdavo“, Plūpsas „žemo, drūto balso“, Šauklỹs „labai garsiai kalba“;

Pravardè atspindi pravardžiuojamojo kompleksiją, tikètina fonetinè asociacija, plg. Štrùlis ir storùlis.

3 Arklys buvo sartas.

4 Ilgų ūsų turẻjimas fonetiškai sugretintas su specifinio gyvūno pavadinimu Usūrinis šuo (pavadinimas susiformavęs pagal Rusijos Usūrijos regioną, iš kur ir kilęs gyvūnas), taip sukuriant kitą prasmingą žodị. 
d) fiziologija. Organizmo fiziologinių procesų motyvuoti asmenvardžiai charakterizuoja būtiniausių gamtos poreikių nesuvaldymą - dujų leidimą, šlapinimąsi: Bèzelis „dažnai gadindavo orą“; Mỹžteris ,ilgai ị kelnes darydavo";

e) potencija. Potencinès žmogaus ypatybès charakterizuoja fizinius aspektus: negalią, sveikatos ydas, žmogaus greitumą / lètumą ar pajẻgumą: Grankùlkè f. „vikri ir stipri“, Kiškio Lüpa „su perskelta lūpa ir gomuriu“"

Pastebèta, jog neretai pravardès pasitelkiamos norint pašiepti trūkumus, pavyzdžiui, raišumą - Klišóji, Cỹrule f. „labai nedidelio ūgio“ ar kokị neịprastą, retai pasitaikanti dalyką, pavyzdžiui, pernelyg įmantrią šukuoseną - Skiauterée. Dažnu atveju pravardès suteikiamos opoziciniu principu (motyvacija pabrěžiama priešingybę atliepiančia realija): Smilgêle f. „labai stora“, Gražuoliùkas „,negražaus veido“, Trumpnõsis „itin didelès nosies“.

2. Pravardès dèl veiklos. Šiek tiek mažiau nei trečdalis tiriamosiose apylinkèse užfiksuotų pravardžių nurodo ten gyvenančių žmonių veiklos įvairumą. Tokias pravardes gaunantys žmonès išsiskiria iš kolektyvo savo amatu ar užsièmimais, kokiu nors pomėgiu, daikto turejjimu ar polinkiu, vienkartine situacija, išprovokavusia pravardès atsiradimą:

a) pomègis, ko nors turejjimas, polinkis. Šie veiklos principai kur kas labiau charakterizuoja ir atspindi žmogaus būdo ypatybes už bet kokią kitą veiklą: Brãčiaus Pỹpe „rūkè pypkę“, Buñdelis ,žaidžia futbolą pasièmęs batoną“, Laĩvas „turèjo krovininę mašiną ZIL ir ją vadino savo laivu“, Blizgùtis f. „turèjo daug papuošalų“, Kristalìne f. ,„per daug save prižiūri“, Dìdpranis „,užaugino daug vaikų“, Karolýnka f. „labai mėgsta nešioti karolius“, Neválgęs „mėgsta gerti, greitai nusigeria ir teisinasi, kad buvęs nevalgęs“, Gỹbkis ,,vogè įvairius daiktus nuo žmonių kiemų“, Činčìas „rinkdavo nuorūkas“;

b) amatas, užsièmimas. Šio pogrupio pravardžių apeliatyvai paprastai atspindi amato turèjimą, profesiją ar kitą užsièmimą, garantuojantị pragyvenimo šaltinị: Šê̌šininkas „,gaude šeškus“, Kranìstas „ilgą laiką dirbo kranistu“, Kryždirbùkas „drožinėjo kryžiukus“; Malũnininkas „malè miltus, dirbo malūne“, Vargamìstras „dirbo vargonininku“;

c) vienkartinè situacija. Būna atvejų, kai pravardès atsiradimą išprovokuoja tam tikros vienkartinės situacijos, dažniausiai aplinkiniams atrodančios komiškai arba graudžiai. Tokios pravardès yra itin individualios ir unikalios: Molinikee f. „molinis tvartas užgriuvo ant karvès“, Galgõno

Pravardè Kiškio Lúpa yra motyvuota dẻl perskeltos lūpos ir gomurio, kurie priskirtini sveikatos ydoms (žmonėms, ypač vaikams, su šiomis ydomis paprastai būdingi kalbos, kvėpavimo sutrikimai). 
Šaknìs „,gèrè daug degtinès ir visiems sakè, kad ten yra galgono šaknis“, Parkètlente „,pažadejo kaimynams pigiai parvežti parketą, bet taip ir neparveže“", Prūsinẽ êlis „buvo Prūsuose“.

Dažna pravardè, motyvuota dèl veiklos, yra sudaryta iš asmenų pavadinimų, pavyzdžiui, Malūnininkas „malè miltus, dirbo malūne“, Vargamìstras „,dirbo vargonininku“. Tarp jų gali pasitaikyti ir okazionalių, pavyzdžiui, Blizgùtis f. „turejjo daug papuošalų“, Gỹbkis „,vogė įvairius daiktus nuo žmonių kiemų“, ar tropinių, pavyzdžiui, Činčikas ,rinkdavo nuorūkas“.

3. Pravardès dèl būdo. Dešimt pavyzdžiu iš devyniasdešimties yra atsiradę dèl ịvairių individo būdo savybių. Pravardès duodamos dèl ịvairiausių būdo ypatybių, tad beveik kiekvienas asmenvardis nusako ne bendrą charakterinị vaizdą, o kokị vieną ryškesnị elgsenos bruožą. Jos apibūdina tokius charakterio aspektus, kaip emocingumą, ekspresyvumą, judrumą, pasaulèvoką ir pan.: Verksnỹs „labai skundžiasi ir verkauja“, Rèbždà „slunkius, ilgai krapštosi“.

Nereta pravardè, kilusi dèl būdo ypatybių, yra kandi ar ironiška, pavyzdžiui, Šmotêlis „lašinių atpjaudavo po mažą gabalèlį“, Išsišókèlis „mègdavo vadovauti“, Smalabámbis „,vaikščiodavo smalinas“. Kai kurie būdo bruožai išryškejja tik bendraujant ir kliūva aplinkiniams kaip netipiškos ypatybès, ydos, kaip nors paveikusios pravardžių davejus: buvo užgautas jų orumas, išgąsdinti ar priversti klausytis nebūtų dalykų, pavyzdžiui, Pìktvarlè f. „prašmatni, pasipūtusi, nebendrauja“, Baibùlis „mėgo gąsdinti“6, Pagyrùkas „,daug giriasi“, Šnekôrius „,mègsta meluoti ir pagražinti kalbèdamas“.

Rytinèje Šilalès rajono dalyje užfiksuota tik viena pravardè, nusakanti pravardžiuojamojo teigiamo būdo visumą - Gẽras Vaĩkas „buvo geras žmogus“. Tad galima daryti prielaidą, jog teigiamos asmens vidinès ypatybės šilališkius erzina mažiau, vadinasi, yra jiems būdingesnès.

4. Pravardès dèl kalbos turinio. Devynios pravardès iš tiriamųjų asmenvardžių charakterizuoja žmogaus kalbejimo metu bereikalingai vartojamus, aplinkoje išgirstus, nesąmoningai ar nevalingai užfiksuotus žodžius ${ }^{7}$. Tokios motyvacijos pravardès lingvistinėje literatūroje vadinamos delokutyvais. Pagal motyvaciją šiai grupei priklausančios tiriamųju apylinkių pravardès kildinamos dèl pertaro bei kreipinio:

a) pertaras. Šio pogrupio pravardès kilusios dèl asmens vartojamo pertaro (įterpinio reikšmę turinčio apibendrinamojo žodelio, parazitžodžio): Dulkike f. „mègsta vartoti mažybinius žodelius“, Be Juõko „sakydavo be

Gali būti asocijuojamas su lat. bubulis „baubas, baidyklè, kaliausé“ (Karulis 1992, 150).

7 Pravardès, suformuotos iš žodinès ar kokios kitos verbalinès pravardžiuojamojo išraiškos, Europos antroponimijos sistemoje vadinamos delokutyvais arba retrolokutyvais. Delokutyvai / retrolokutyvai priskiriami tam tikrai metonimijos rūšiai (Langendonck 1996, 1230). 
jūka, be jūka, bijau važiūti su arkles“, Karóbka „dirbdamas statybose dažnai vartoja ši žodic“, Gurklỹs „dažnai vartodavo gurkliūju žingsniūju“, Čià Jau „dažnai vartodavo čia jau“, Mùny „,visad sako mùny, nes viskas turi priklausyti jam“;

b) kreipinys. Tiriamosiose apylinkèse fiksuotos pravardès priskiriamos reversiniam bei tikrajam kreipiniui; pasitaikè viena autopravardinè. $\underline{\text { Re- }}$ versinis kreipinys dèl hiperbolès, perdèto vartojimo virsta motyvu susiformuoti jų autorių pravardèms - Veivelis „kitus vadina veiveliukais“" ${ }^{\text {. Ti- }}$ krasis kreipinys lemia ne kreipinio autoriaus, bet adresato pravardę. Toks kreipinys paprastai atsiranda ir yra vartojamas tarp šeimos narių, o kelis kartus išgirstas aplinkinių, ilgainiui ima pravardèti - Brangùtis ,taip tėvas vadino savo sūnų“. Autoịvardijanti pravardè atspindi žodị, kuriuo asmuo pats save vadina, gali net priminti slapyvardi - Ananãsas ,pats save taip vadina“.

Kiekvieno žmogaus kalbos turinys yra savitas ir unikalus, tad klausančiajam dažniausiai kliūva tokie kalbos turinio elementai, kurie gali pasirodyti neicrasti ir vertinami kaip nereikalingas kalbos balastas. Kalbant gali būti vartojami ne tik bendrinès ar tarminès kalbos, bet įterpiami ir svetimos kalbos žodžiai, vėliau tape pravardèmis, pavyzdžiui, Karóbka „dirbdamas statybose dažnai vartoja ši žodị“. Pasitaiko, jog pravarde tampa kalboje dažnai vartojami, ịterpinio reikšmę turintys nesudaiktavardinti prieveiksmiai, pavyzdžiui, Čià Jau „dažnai vartodavo čia jau“.

5. Asociacinès pravardès. Tiriamosiose apylinkèse rasti aštuoni pavyzdžiai, motyvuoti dèl asociacijų, kai pravardè ir vardas ar pavardè susiję panašių garsu sąskambiu. Ši grupè charakterizuoja asmenvardị, o ne pati asmenį, rodo asociatyvų panašumą į kokio nors daikto, augalo, gyvūno ar ypatybės pavadinimą. Šios pravardès neturi jokio santykio su žmogaus išvaizda ar kitais bruožais. Tiriamųiu apylinkių asociacinès pravardès būna fonetinès, pasitaikè viena onomastinè. Pagal motyvaciją pravardès kildinamos iš pavardžių, gerokai mažiau iš vardų:

a) pravardès, kilusios dèl pavardès: Žãlèf. „dèl pavardès Žaldáuskiené, Kukùtis „dèl pavardès Mikùtis“, Ausìkè f. „,dèl pavardès Ausiukýtë“, Karõsas „dèl pavardès Karosáitis“, Pêčius „dèl pavardès Petkêvičius“;

b) pravardès, kilusios dèl vardo: Mopèda f. „dèl vardo Nomedà, nes asocijuojasi su mopèdas“, Saigónas „dèl vardo Sigìtas“, Brikà f. „,dèl vardo Rità";

c) asociacijų sukelia ne tik asmenvardžio pradžia, bet ir skiemenys ar keli garsai. Ilgas pavardes paprastai linkstama trumpinti atsisakant vienos ar kelių priesagų. Toks santykis tarp oficialaus (vardo, pavardès) ir neoficialaus (pravardès) asmens pavadinimo tėra tik žaismas žmogaus vardu. Tad

\footnotetext{
Tiriamosiose apylinkèse veĩvelis reiškia ,ištižèlis“.
} 
pravardžiuojamajam yra tarsi primetama tokia realijos ypatybė, kurios pavadinimas eina pravardès apeliatyvu.

6. Gimininès pravardès. Tarp tiriamųjų asmenvardžių kiek mažiau užfiksuota pravardžių, motyvuojamų giminystès ryšiais. Šios pravardès nurodo ryši ir santykius tarp atskirų šeimos narių:

a) patroniminès pravardès. Šio pogrupio asmenvardžiai turi tiesioginę nuorodą i tėvo, motinos ar protėvių vardą, pravardę. Tokia pravardè tarsi užkonservuoja vieno iš tèvų asmenvardį, tad neturi konotuojamos reikšmès, nes paveldèta jau be semantinio turinio: Albiniùkas ,pagal tèvo vardą Albìnas“, Vandùkas „,pagal mamos vardą Vánda“, Ipolìnis „,pagal tèvo vardą İpolis“, Lapùtis „pagal motinos prvd. Lãpe““, Tekìnis „,pagal motinos prvd. Tekìnis“, Saldžióji f. „pagal močiutès pravardę Saldi““;

b) še i myni n è pravardè. Šiam pogrupiui priskiriama pravardè charakterizuoja tiesiogini šeimyninès bendruomenès ryši - Dé $d k u s$,augino sesers vaikus".

Kad būtų išvengta painiavos ir pravarde tiesiogiai nurodytų konkretų asmenị, beveik visos pravardès yra išvestinès, t. y. jomis eina pakeisti tėvų ar protèvių asmenvardžiai, pavyzdžiui, Saldžióji f. „,pagal močiutès pravardę Saldì“, Vandùkas „pagal mamos vardą Vánda“. Pastebėta, jog sūnų pravardès sudaro daugumą. Sūnūs, remiantis LP, paveldèję tèvų asmenvardị, ir toliau juo vadinami net santuokoje, o dukterys dažnu atveju gauna pravardę, padarytą iš vyro asmenvardžio.

7. Pravardè dèl gyvenamosios vietos. İvardijimo būdas pagal gyvenamąją vietą laikomas archajišku, toks asmens individualizavimas yra vienas seniausių, davęs pamatą rastis pavardèms (LP 1995, 109). Tačiau šiais laikais, matyt, nebeaktualus. Tarp tiriamųjų asmenvardžių užfiksuota tik viena pravardè, nurodanti ankstesniojo ūkio šeimininko asmenvardi - Žeimỹs „nusipirko Žeimio ūki ir ten gyvena“.

I šv a d o s

Šilališkių pravardžių motyvacija įvairi, susidaro tos pačios motyvacinès grupès, kaip ir kitur Lietuvoje. Tačiau ju pasiskirstymas pagal gausumą tiriamosiose apylinkèse šiek tiek kitoks nei visoje Lietuvoje, nors iš dalies sutampa su Žemaitijai būdingu.

Pravardès, kilusios dèl fizinių ypatybių, beveik visuose Lietuvos etnografiniuose regionuose sudaro didžiausią motyvacinę grupę. Tiriamosiose apylinkèse jos taip pat pasižymi gausumu - apie $39 \%$. Žemaitijoje ir tiriamosiose apylinkèse dažniausiai užkliūva individo išvaizdos ypatumai: labiausiai akcentuojami kūno sudejjimas bei ūgis ir plaukų ypatybè, pavyzdžiui, Spyglỹs „,aukšto ūgio ir plonas“, 
Baltplaũkè f. „turi juodus kaip čigonès plaukus“. Žmogaus motorika, kalba, fiziologija bei potencija taip pat įtaigios formuojant pravardę, tačiau šios ypatybės tiriamosiose apylinkèse pasiskirsto tik po vieną kitą pavyzdị.

Kaip niekur kitur Lietuvoje, rytinejje Šilalès rajono dalyje gausumu pasižymi pravardès, motyvuotos dèl veiklos, jos sudaro $22 \%$. Tiriamosiose apylinkése labiausiai išskiriami žmonès, pasižymintys savo pomėgiu, polèkiu ar ko nors turejjimu, tad tokio tipo pravardès užima apie pusę asmenvardžių, motyvuojamų dèl vienokios ar kitokios veiklos, pavyzdžiui, Karolýnka f. „labai mėgsta nešioti karolius“, Buñdelis „žaidžia futbolą pasièmęs batoną“. Šiose apylinkèse taip pat užfiksuota viena kita pravardè, motyvuota dèl žmogaus amato, užsièmimo, vienkartinès situacijos.

Pravardès dèl būdo, tiriamosiose apylinkèse sudarančios $11 \%$, yra dažnesnès nei visoje Lietuvoje, tačiau panašiai pasiskirsto kaip ir Vidurio Lietuvoje. Beveik visos šios grupès pravardès turi neigiamą konotaciją, pavyzdžiui, Šmotêlis „lašinių atpjaudavo po mažą gabalèlį“, ir tik viena pravardè - Gẽras Vaĩkas „buvo geras žmogus“ - turi teigiamą konotaciją. Toks reiškinys neatspindi žemaičiams būdingos realijos ị per dideli gerumą ar santūrumą žiūrèti su nepakantumu.

Pravardès dèl kalbos turinio rytinèje Šilalès rajono dalyje taip pat sudaro apie $10 \%$. Visoje Lietuvoje šiu pravardžiu aptinkama kiek dažniau. Kaip ir Žemaitijoje, tiriamosiose apylinkèse dauguma pravardžių yra sudarytų iš pravardžiuojamojo pertaro, pavyzdžiui, Gurklỹs „dažnai vartodavo gurkliüju žingsniüju“. Po vieną pavyzdi priskiriama reversiniam, tikrajam kreipiniams bei autoịvardijančiai pravardei.

Lyginant su visa Lietuva asociacinès pravardès rytinèje Šilalès rajono dalyje užfiksuotos gausiau. Jos sudaro $9 \%$ tiriamųiu pravardžių. Dauguma jų kilusios iš pavardžių, pavyzdžiui, Kukùtis „,dèl pavardès Mikùtis“, kitos - iš vardų, pavyzdžiui, Mopèda f. „dèl vardo Nomedà, nes asocijuojasi su mopèdas“.

Skirtingai nuo visos Lietuvos, kur asmenvardžiai, motyvuoti giminystès ryšiais, užima kone trečdali visų pravardžių (Dzūkija, Aukštaitija), tiriamosiose apylinkèse, panašiai kaip ir Žemaitijoje, jos yra gana retos - sudaro apie 8 \%. Tačiau, skirtingai nei žemaičiuose, rytineje Šilalès rajono dalyje yra kur kas gajesnẻ patroniminių pravardžių tradicija - čia jos sudaro absoliučią daugumą, pavyzdžiui, Ipolìnis „pagal tèvo vardą İpolis“. Ir tik viena pravardè, charakterizuojanti šeimynini ryši - Dé dkus ,augino sesers vaikus“.

Pravardès dèl gyvenamosios vietos visoje Lietuvoje yra negausiai fiksuojamos. Ne išimtis ir rytiné Šilalès rajono dalis, kur pravardžių, kilusių dèl šios motyvacijos, tradicijos yra menkiausios - čia aptikta tik viena pravardè, charakterizuojanti gyvenamąją vietą - Žeimỹs „nusipirko Žeimio ūkị ir ten gyvena“. 
Kaip niekur kitur Lietuvoje, tiriamosiose apylinkèse nepavyko užfiksuoti pravardžių, motyvuotų dèl turto, kilmès ar tautybès. Būtų subjektyvu teigti, jog rytinès Šilalès rajono dalies gyventojams šios ypatybès visai nekliūtų, nes remiamasi tik 90 pavyzdžių, kurie negali visiškai atspindèti tiriamųjų apylinkių realijos.

\section{Literatūra}

Aleknavičienè 2009 - Ona Aleknavičienė. Kazlų Rūdos ir jos apylinkių gyventoju pravardès. Lietuvos valsčiai. Kazlų Rūda. <http://www.llt.lt/pdf/kazlu_ruda/kalba.pdf>.

Aleknavičienė 2005 - Ona Aleknavičienè. Tauragniškių pravardès. Lituanistica. <http://www.ebiblioteka.lt/resursai/LMA/Lituanistica/0503_06_Lit_047_070.pdf>.

Jakaitienė 1980 - Evalda Jakaitienè. Lietuviu kalbos leksikologija. Vilnius: Mokslas.

Gritėnienè 2006 - Aurelija Gritėnienè. Augalu pavadinimu motyvacija šiaurés panevėžiškiu patarméje. Vilnius: Lietuvių kalbos institutas.

Gudavičius 2000 - Aloyzas Gudavičius. Etnolingvistika. Šiauliai: Šiaulių universiteto leidykla.

Karulis 1992 - Konstantīns Karulis. Latviešu etimoloğijas vārdnīca. Rīgā: Avots.

Langendonck 1996 - Willy Van Langendonck. Bynames. Name Studies, 1228-1232. Berlin: Walter de Gruyter.

LP 1995 - Alvydas Butkus. Lietuviu pravardès. Kaunas: Aesti.

Wilson 1998 - Stephen Wilson. The Means of Naming. London: UCL Press.

\section{Ramutè Dabrytè}

\section{WHAT IS THE NICKNAME-GIVING OF PEOPLE FROM THE ŠILALE DISTRICT?}

Summary

This article presents an analysis of the nicknames of the residents of the eastern part of Šilale district, mainly of Kaltinènai, Bijotai and Upyna country-side districts. The nicknames are originals and have not been researched in Lithuanian linguistics. There were found 90 cases. The aim of the article is to study motivation of nicknames in the eastern part of the Šilale district. The present work is based on the descriptive, investigative-analytical and comparative methods.

The analysis of the material proclaims that the main reason for the appearance of Šilale district nicknames is subjective-psychological and formalizes the lack of personal characteristics and deviation from the community standards.

In accordance with the motivating personal features, the analyzed nicknames are classified into the following groups: 1) nicknames related to physical properties. Such nicknames comprise about 39\% of all examined nicknames. Most emphasis is given to a person's appearance: fat, short, having exceptional hair color, long-nosed, long-moustache and long-bearded, and people resembling some kind of personage. Features of a person's body movement, language, physiology 
and potency are rarely observed; 2) nicknames related to activities. Such nicknames (they comprise about $22 \%$ of all nicknames) mostly reflect people hobbies, desires, and possession of an object. These nicknames are also often given to craftsmen or people engaged in activities that are considered as a source for life. A single situation little influenced the appearance of nicknames, but such nicknames are very unique; 3) nicknames related to person's character. There are not much of such nicknames - about $11 \%$ of all nicknames. Almost each nickname stresses different behavioral traits: some ironically may stress avarice, leadership, while others become apparent during communication, as they reflect arrogance, brag, lying. Only one nickname refers to a positive person's feature; thus, the people should be notable for temperance and sincerity; 4) nicknames related to speaking content or in other words delocutives. Such nicknames (they comprise about $10 \%$ of all nicknames) are frequently used to define the byword (favorite word or phrase). Less frequently nicknames are given because of the appeal to somebody, which can not only become the addressee's, but also the addresser's nickname, or even reflect a word that a person calls himself; 5) associational nicknames comprise about $9 \%$ of all nicknames. Their motive - the similarity of a surname, and less often of a name to the name of a thing, animal, or feature. Almost all associations are phonetic and only one is onomastic; 6) family nicknames comprise about $8 \%$ of all nicknames. Patronymic nicknames are equally often made from the nickname and the name of a mother, father or a grandmother. Familial nicknames are very rare; 7) the only nickname relates to person's place of residence and the motive have become the nickname related to former owner of a homestead.

The material of the research, that is 90 nicknames, can not fully reflect reality of the investigated districts, but it could be a great source for further regional research of nicknames. 